\title{
\#INDEBTED: Disciplining the Moral Valence of Mortgage Debt Online
}

\author{
NOELLE STOUT \\ New York University \\ (D) http:/ / orcid.org/0000-0002-8442-9087
}

Since 2007, 14 million homeowners in the United States have lost their homes to foreclosure, the highest rate of bank seizures in national history. This massive wave of dispossessions has spawned an acute rise in homelessness, bankrupted entire cities, and caused the irreparable loss of generations of family wealth. Given that homeownership has served as the foundation for American middle-class imaginaries since World War II, it is inevitable that these inordinate rates of default have transformed the meaning of mortgaging and indebtedness within the United States. Indebtedness, as David Graeber (2011, 390) suggests, has become ever more tied to moral personhood in modern times, in that what he terms "the governing classes in the United States" have linked the ability to repay debt to moral standing. Yet in a context in which financialization has disrupted the social contract implicit within debt ties, those carrying insurmountable mortgage debt have begun to question the meaning of indebtedness and the moral assumptions about mortgage default. These everyday debates about homeowners' duty to pay on underwater mortgages have played out largely in the virtual world of online forums and blogs. ${ }^{1}$

These disputes about the stigma of delinquent homeownership and mortgagors' moral obligation to repay mortgages depart radically from those that characterized previous American foreclosure crises. For example, Kathryn Dudley (2000) opens her ethnography of the 1980s U.S. farm foreclosure crisis with the 
story of Dewayne Berg, a farmer facing the loss of the family farm who disappeared from his Midwestern home, leaving his wife and sons to suffer months of grief and speculation. Berg was eventually discovered hiding out in Canada, a testament to the stigma and community judgment affecting farmers confronting foreclosure. Dudley observes the animosity community members expressed toward families undergoing bank seizures; instead of questioning how lenders had pushed cheap credit onto farmers, Berg's friends and neighbors concluded that anyone who lost a farm had "done something to deserve it" (Dudley 2000, 5). But had Berg faced foreclosure during the 2008 mortgage crash, might the image of him driving his muddy pickup truck to Canada have been transformed into one of him hunched over the glow of a laptop, deciding to abandon his debt rather than his family?

I argue here that homeowners confronting foreclosure in lower-middle-class and middle-class Northern California neighborhoods are reconfiguring longstanding American interpretations of indebtedness through forays online. I focus on homeowners participating in interactive online forums arising in the aftermath of the 2008 crash to show how mortgagors are moralizing debt nonpayment and disciplining the politics of stigma. To map this terrain, I analyze user-generated, national online foreclosure forums and sites including advice boards, posts on social networking sites, and blogs emerging since 2008 in combination with ongoing ethnographic research among people confronting foreclosure in California's Sacramento Valley. The predominantly white and Latino homeowners presented here neither identified as activists nor were involved with debt-related social movements such as Occupy Wall Street or Strike Debt, which emerged from the financial crisis. Yet they produced and participated in what I describe as online publics of indebtedness through which they joined a broader, ad hoc social discussion in which Americans question the established moral dimensions of debt repayment after the 2008 foreclosure epidemic. Applying a multiattentional approach (Boyer 2007, 87), which considers the technological effects of media and the ways media shape relations between people, I show how the distinct experiences of participating in anonymous and semipublic online domains proved central to shifts in homeowners' interpretations of debt and default. I argue that unlike political activists, California mortgagors participating online reconsider the politics and morality of mortgage default for certain, but not all, homeowners. They deem specific mortgagors worthy of sympathy, offering them nonjudgmental support when they walk away from underwater mortgages, yet ultimately they do not abandon wholesale the moralization of debt. 
In a context of widespread foreclosure, homeowners often reframe creditdebt bonds through moral narratives in ways that invite a reconsideration of longstanding anthropological inquiries into moral economies (e.g., Edelman 2005; Scott 1977; Thompson 1971). ${ }^{2}$ By focusing on eighteenth-century contexts or modern peasant societies, canonical anthropological scholarship on moral economies risks perpetuating the notion that late-capitalist economies function as amoral spheres in which economic activity remains untouched by ideas of propriety (Griffith 2009). Whereas peasants working the land are often seen as articulating utopian visions of a world in which morals determine economic fairness, the moral narratives of American suburbanites struggling with financialized mortgage markets and venturing online for assistance often go unrecognized. By relocating these moral economic narratives, so often linked to pastoral ideals of land and belonging, to middle-class suburban homeownership and online collectives, I show how contemporary hypercapitalist debt ties are complexly linked to the disciplinary regimes of moral discourses. If the ethnographic record has typically portrayed moral discourses as the power of creditors over debtors, ethnographic exceptions emerging after the mortgage crash indicate the shifting contemporary terrain of credit-debt relations (Peebles 2010).

These moral counternarratives regarding indebtedness respond to the rise of a contemporary capitalist context that Andrew Ross $(2013,11)$ describes as a creditocracy, where financiers wrap debt around every possible asset and income stream, requiring basic goods to be debt-financed and making indebtedness the precondition for acquiring life's necessities. Ross $(2013,32)$ argues that breaking the promise to repay is taboo in a creditocracy and ponders what will happen when the public psychology around debt retreats from automatic compliance with the morality of payback. An examination of homeowners in the context of the financial crisis, in which debt is increasingly defined as the moral obligation to repay (High 2012, 2), is therefore critical to understanding a shift in Americans' perceptions of debt obligations. In her research on Michigan's foreclosure crisis, for example, Anna Jefferson (2013) found that homeowners produced narratives of walking away from mortgage debt as a moral critique of corporate greed and government ineptitude. Likewise, since the 2008 crash, many Northern California homeowners with distressed mortgage debt have harnessed the authority of moral narratives to question traditional credit-debt ties, articulating online counternarratives that recast debt nonpayment into a moral stance.

Online publics are easily overlooked, however, when evaluating the impact of the 2008 crash, because most users participate from the privacy of their 
homes - sitting at desks and kitchen tables, or perched on sofas and beds. Although a wealth of quantitative scholarship examines the national, familial, and neighborhood effects of unprecedented rates of foreclosure, few scholars have explored American homeowners' experiences (Jefferson 2013; Reid 2010), and none have examined the discourses and practices arising from online domains in the wake of the 2008 crash. During thirteen months in the Sacramento Valley, one of the fastest-growing and hardest-hit regions in the nation, I studied homeowners experiencing foreclosure in neighborhoods with distinct racial and economic demographics. Here, I focus on a subset of these seventy interlocutors: twenty homeowners in middle- and lower-middle-class neighborhoods who consistently turned to the Internet to navigate the profound daily impacts of the foreclosure crisis and who, through their online encounters, began to rethink the meaning and moral valence of indebtedness. ${ }^{3}$ I met many of these homeowners through close family and friends who had experienced foreclosure in the region, and contacted others through foreclosure counselors at nonprofit organizations with which I worked.

Online publics proved especially appealing to homeowners who hesitated to identify as unable to repay their debts but needed advice on impending foreclosures and wanted to participate in a broader discussion of the precariousness of economic life in the wake of the Great Recession. The recent rise of interactive Web 2.0 media platforms, as anthropologists have shown, offers new opportunities for users to shape online dialogues and redefine public engagement (Boellstorff 2008; Ginsburg 2012; Miller and Horst 2012; Postill 2012). Ironically, the same speed, automation, and computer interconnectivity fundamental to the financialization of mortgage markets that spawned the recent crash (e.g., Langley 2007; Pinch and Swedberg 2008; Poon 2008) have enabled significant discussions of mortgage default among homeowners dispossessed by these trends. Through interactive online modalities, for example, participants question the shame of foreclosure, critique mortgage lenders, validate others' choice to abandon underwater loans, and advocate staying in homes without paying, forms of refusal previously considered unethical within normative models of American middleclass propriety. Yet even as homeowners protest the increasing unfeasibility of post-World War II American middle-class life projects, long defined by stable employment, homeownership, and higher education, participants in online forums redefine respectability rather than abandon the notion entirely. ${ }^{4}$ 


\section{SHIFTING MORAL ECONOMIES OF MORTGAGE DEBT}

Beginning in the late 1930s, debt became socially accepted within the middle class, as the moral dimension of owing money dissipated when consumer debt came to support but also discipline every facet of daily life for those who gained access to it (Calder 1999, 20). Before 1917, U.S. lenders were prohibited from charging profitable interest rates, reselling debts, or borrowing against them (Hyman 2011a, 1). Americans did borrow, industrial workers especially, but the stigma of debt meant that they borrowed privately from a subterranean world of loan sharks, pawnbrokers, and retailers (Calder 1999; Hyman 2011a). In the 1920s, consumer credit entered mainstream middle-class American social life, as business and government collaborated to enable Americans to purchase the goods of the developing manufacturing economy. Credit expanded further in the 1930s, with New Deal policies expanding consumer credit and federal mortgaging programs after the housing crash of the late 1920s. Consumer credit continued to fuel post-World War II suburban fantasies of the good life, as financial industries offered easy credit to white men and married white women, enabling them to purchase homes, automobiles, and consumer goods (Hyman 2011b). Americans borrowed unprecedented amounts on the assumption that their jobs were stable and their incomes would keep growing. Homeownership became central to bluecollar and middle-class class status, as those who carried so-called good debt were considered good citizens (Williams 2004). Whereas before the 1920s, it had been shameful to owe money, the expansion of consumer credit allowed long-term borrowing and debt repayment to become central to middle-class notions of stability and security.

As government mortgage programs expanded alongside consumer credit industries, society's disapproval shifted away from the usurious mortgage itself to the property owner who defaulted on a loan. ${ }^{5}$ Failure to repay debt - rather than merely having debt_-brought about social stigma and humiliation, as well as financial punishments such as bad credit, eviction, and repossession. ${ }^{6}$ Hence, for post-World War II generations, so-called financial failures such as foreclosure and unemployment presented what Katherine Newman (1988) describes as the "fall from grace," the embodiment of American middle-class anxiety about downward mobility. In the case of mortgaging, government agencies and financial industries have intensified these tactics to cultivate borrowers' fear, shame, and guilt about foreclosures (White 2010a). Traditional forms of shameful publicity, such as publishing delinquent mortgagors' names in newspapers and posting fore- 
closure notices on the fronts of houses, have disgraced homeowners and led them to pay even against their own financial best interests.

Assumptions about the value of homeownership and debt repayments have been called into question following the recent housing market collapse. In Sacramento between 2007 and 2008, mortgage defaults increased sixfold, with foreclosures jumping 482 percent and one in every sixty-seven households filing for foreclosure. For the following five years, California's capital city would consistently rank in the top ten in foreclosures per capita in U.S. metro areas (Baker, Stein, and Eiseman 2008). Despite unprecedented rates of mortgage default, the stigma against default persisted in the early years of the epidemic. By 2009, seven out of ten mortgagors surveyed who had defaulted still believed it was unacceptable to stop payments on an underwater mortgage (Fannie Mae 2010). Local Sacramento culture heightened the stigma of nonpayment, as the dominant industries of farming, manufacturing, and government fueled blue-collar aspirations for middle-class status and linked homeownership to moral personhood. ${ }^{7}$ After the crash, Sacramento Valley homeowners expressed fears that their friends, family, and coworkers would reject them or view them as incompetent or irresponsible for falling behind on mortgage payments. These were the sentiments they cited as leading them to make their initial forays online, where they could solicit advice anonymously.

Once online, many homeowners began to rethink their obligations to repay mortgage debts as they came to grasp the role of Wall Street investment firms in triggering the crash, a process that online participants often detailed in their posts. In the decade leading up to the collapse of mortgage markets, Wall Street investors took an interest in otherwise conservative mortgage markets, rapidly securitizing mortgage debt and trading debts as commodities on derivatives markets. Roping mortgage debts into complex financial transactions, as Karen Ho (2009, 2010) has argued, enabled Wall Street investment bankers and traders to leverage risk to turn quick and unprecedented profits, while also outsourcing risk to individual homeowners and the government, which many financial industry architects assumed would provide a bailout when the market collapsed. ${ }^{8}$ Even as mortgage lenders such as Countrywide Financial, Lehman Brothers, Bank of America, and Wells Fargo were found guilty of illegal sales techniques and pushing through wrongful and illegal foreclosures, homeowners were still urged to honor financial obligations that often ran counter to their own financial interests (White 2010a, 972). These frustrations and resentments at lenders and the government constituted major distinctions between mortgagors who continued to pay on un- 
derwater loans and those who chose to abandon mortgage debts after the crash (White 2010a). In the wake of the foreclosure epidemic, many homeowners participating in online collectivities came to recognize a double standard in the morality of debt repayment and began reinterpreting the meaning of dispossession.

\section{MEDIA CRITIQUE AND COUNTERPUBLICS}

The collapse of U.S. mortgage markets inspired pundits and broadcast journalists to debate how best to regulate risk in financial markets and evaluate homeowners' responsibility to pay on underwater mortgages. ${ }^{9}$ In the years immediately following the 2008 crash, prominent news networks demonized mortgagors who defaulted on home loans, often accusing them of immorality and a lack of patriotism (White 2010b, 999). Commentators, radio shows, and op-eds frequently labeled defaulting mortgagors "unseemly," "offensive," and "unethical," and they likened defaulters to "deadbeat dads who walk out on their children" or to appeasers who would "give up" and hand over Europe to the Nazis (White 2010b, 999). ${ }^{10}$ Black-oriented media, traditionally more politicized, performed no differently than the mainstream press in terms of blaming the crisis on mortgagors' poor decision-making (Squires 2012). Local news reports in the Sacramento Valley proved more sympathetic to families facing eviction and default, as the scope of the crisis appealed to the empathy of resident reporters and writers. Yet to preserve the illusion of journalistic fairness, English- and Spanish-language networks such as Univision gave equal weight to the perspectives of lending executives at the expense of more in-depth analyses. ${ }^{11}$ Generally, media discussions failed to analyze how rampant financialization, the targeting of complex financial products to unknowing consumers, and illegal lending practices contributed to the crash. A majority of news networks ignored how racial and economic inequalities endemic to American late capitalism contributed to the foreclosure epidemic (Chakravartty and Ferreira da Silva 2012; Roitman 2013; Shimpach 2012).

Online forums gave homeowners an opportunity to contest these media representations, as users reposted and commented on articles and videos from mainstream press outlets like the New York Times, CNBC, CNN, and the Sacramento Bee. For example, one article in the online news aggregator Huffington Post (Goodman 2012), on the possibility of using eminent domain to fix Sacramento's mortgage meltdown, garnered more than three thousand comments in eight hours. In another online forum, a participant using the online name Natomasucks (a riff on the middle-class suburban development devastated by the housing crash) reposted 
an article from the Sacramento Bee in which banking executives recommended loan modifications instead of mortgage default. The thread, entitled "To Walk Away or Not Walk Away?," inspired immediate commentary as another user named Coakl replied: "Loan executives are looking out for their interests; Don't play their game. . . . These loan executives are trying to pull one last sub-prime trick: persuading millions of upside-down homeowners to ignore the market collapse and make payments." Although the press heralded loan modifications as a source of much-needed assistance for homeowners, online posters often agreed that lenders misled homeowners by claiming that modifications would be in their interest. This discussion, suggesting that default was preferable to working with lenders to make payments, took place between 12:30 a.m. and 3:00 a.m. just days after the article's publication, showing the rapid-paced responses that online forums allowed. Online users whose days were filled with work and family responsibilities participated in public debate and critique even in the early morning hours. ${ }^{12}$ Through online forums and the commentary sections of news articles, posters could anonymously and immediately challenge dominant media narratives of the crisis and debate alternatives to mortgage repayments.

By countering dominant media narratives, online homeowners could position themselves as media critics and producers without having to overcome the hurdles to mainstream media participation (cf. Boyer 2007, 78). In this way, online publics of indebtedness suggest an evolution of counterpublics, self-organized social spaces that depend on anonymity and an immediacy of response that empower stigmatized participants to formulate critiques (Berlant 2000; Fraser 1990; Negt and Kluge 1993; Warner 2002). The lack of editorial oversight and the ready access to Internet connections at all times of day or night helped online critics to circumvent the hurdles to audience participation erected by broadcast journalism. As Dominic Boyer (2013, 128, 136) points out in his ethnography of news production in a digital age, the technologies of digital communication associated with Web 2.0 developments fuse what he describes as "lateral and radial messaging potentials" to constitute interactive publics that sharply depart from twentieth-century models of Keynesian publics and broadcasting. The fragmented online collectives that erupted to critique and undermine the authority of broadcast media suggest more than a traditional public-counterpublic dialectic; they also show how digital media might be used to realize the promise of Jürgen Habermas's (1989) ideal democratic public sphere, through which alternative orientations toward debt could become viable. 


\section{DISEMBODIED AUTONOMY: ONLINE ANONYMITY AND DEFAULT}

Consider Jack McGill, a thirty-three-year-old white computer programmer who had dropped out of high school and taught himself to code. McGill married his high-school sweetheart, a Latina preschool teacher, with whom he had four children and had purchased a house in a middle-class suburb of Sacramento. I sat with McGill on his sofa as he went online, guiding me to his favorite stops: Reddit and the Craigslist Housing forum. ${ }^{13}$ After Bank of America denied his mortgage modification application, McGill discovered foreclosure-related discussion forums called subreddits, including categories such as "economy," "personal finance," "legal advice," and "WTF." According to Reddit, McGill fit the profile of their registered users, who tended to be socially liberal and interested in politics, with the slim majority of users being college-educated eighteen- to thirty-four-yearolds. McGill pointed to the Reddit posters who argued that speculators, not homeowners, drove most foreclosures. One user, Check-Please, argued that homeowners were "scammed into sub-prime [mortgages] by greedy brokers" and maintained, like many Reddit posters, that the mainstream press and the public unfairly scapegoated homeowners.

As McGill pointed out, both Craigslist and Reddit ensure a high level of anonymity, as users' identifying information remains private. In addition to criticizing lenders, posters on the forums recommended abandoning underwater mortgages as a response to personal hardships related to pending foreclosures, including mortgage troubles when contending with divorce, depression, suicidal thoughts, and chronic illness. Alongside these confessions, users provided detailed accounts of their mortgaging struggles, including concrete figures describing their loans, income, credit card balances, home prices, savings, and standing consumer debt. They freely exchanged financial information and opinions that would be considered taboo to share in face-to-face social settings, especially among Americans aspiring to middle-class status. That these novel forms of anonymous digital public-making arose in response to and shaped interpretations of indebtedness is not coincidental. Debt, as Janet Roitman (2005, 212) emphasizes, can offer a means to affirm or deny sociability, as it forces subjects to mark critical and, at times, strategic stances within social imaginaries. Rather than a negative social force, online indebtedness incites mediated forms of sociality.

In similar cases, many online participants encouraged homeowners to halt payments, often describing the relief and freedom they had felt when defaulting. When Renaldo Suarez, a fifty-six-year-old Latino veteran, faced foreclosure after 
his wife died from cancer, a friend guided him to online housing forums for advice. Suarez had moved to Sacramento from Los Angeles in the 1970s after securing a job as a factory manager, but he transitioned into educational services as the Sacramento Valley became deindustrialized in the 1980s. Now Suarez lived on a fixed income and owed nearly twice as much as his home was worth. After the loan counselor told him he would have to get a roommate to qualify for a modification, he posted his financial details on Craigslist in an attempt to solicit an alternative perspective. Many respondents suggested that he stop making payments but stay in his home:

Jcasetnl: I bet he could just stay in it. Seriously. There's so many foreclosures in Sacramento ... .

Whiskey_McSwiggens: I'm not sure how, but my neighbor [. . .] has been living in his house for over a year without paying mortgage payments and it's a bank-owned house. He's obviously going to lose the house at some point, but not until someone buys the house from the bank. OP [Original Poster] should look into how to do this.

Chadcf: There is now [sic] 'how to do this'. It just involves not moving, until the Sherrif [sic] comes to kick you out. The bank isn't letting them stay there because they have some desire to not make people homeless, they do it because there are a ton of foreclosures and they have a huge backlog to deal with and if the house is upside down it's not like it's going to be any more profitable to move quickly.

Suarez eventually decided to stop payment on his mortgage, but he continued living in his home for two years until he was evicted. "As a man, I grew up knowing that you do the right thing. But this game is fixed. They [the banks] aren't doing the right thing, so why would I?"

In anonymous online domains, a diverse cross-section of homeowners similarly articulated the responsibility of lenders to assist homeowners and went further, even questioning the value of applying for loan modifications and encouraging mortgagors to default. While lenders shouldered no legal responsibility for modifying underwater mortgages, posters pointed to lenders' refusals to renegotiate mortgage contracts or to halt foreclosure proceedings for worthy candidates as evidence of the illegitimacy of some mortgage debt in the context of the crash. Walking away from underwater mortgages no longer suggested an unethical response to crushing debt, but a choice justified by the shifting landscape of credit-debt ties. 
In the aftermath of the mortgage crash, anonymous online forums encouraged mortgagors to experience a sense of freedom in that they were protected by privacy and bolstered by the immediate responses of other posters. This sense of disembodied autonomy inspired them to question other forms of subjection, namely, what they identified as unfair debt servitude. In this way, anonymous online publics resonated with Northern Californians dispossessed by late liberal political economies. Anonymity protected participants from social stigma while allowing for a continued investment in the autological premises of late liberalism. Mortgagors could engage in frank and heated discussions about personal economic hardship that still remain taboo in many middle-class social circles throughout the Sacramento Valley, while permitting a heightened sense of individualism. Each poster could present his or her story as unique in its details but as one simultaneously linked with other participants' narratives. The pursuit of advice online also demanded that people become active consumers of knowledge, with the pursuit of financial competency as a normative ideal - a mark of late liberal regimes. As central as the content of forums, the form and medium of online publics of indebtedness generated experiential qualities of detachment and independence that inspired a reconsideration of the duty to repay underwater mortgage debts. If the anonymity and immediacy of Reddit and Craigslist online forums encouraged a detachment from the social contracts implicit in mortgage debt ties, the connectedness and performativity of social networking sites generated new ways of feeling about debt, though it de-emphasized strategies for outright debt refusal, as I show in the next section.

\section{SEMIPUBLIC ONLINE NETWORKS AND DEBT AFFECT}

"I didn't tell anyone what we were going through, not even my mom," Rachel Leibrock, a white journalist in her thirties, told me as we sat in a coffeehouse in Sacramento's midtown district and she described facing foreclosure after she lost her job at a local newspaper. 14 "I felt like I had failed as an adult." Leibrock eventually decided to tell her foreclosure story in a feature article she had written for the Sacramento News \& Review, a weekly paper with a sizable online readership. She had been inspired to "go public" after reading a blog post in the Huffington Post about a homeowner who had fallen victim to dual-tracking, an illegal practice in which a homeowner pays into a trial modification program, but the loan servicer proceeds with foreclosure regardless.

In her article, Leibrock describes confronting a high-stakes Kafkaesque world of lost paperwork and endless phone calls with bureaucrats who monitored her 
monthly expenditures as she attempted to modify her mortgage. Ultimately, her loan administrator, Coldwell Banker, proceeded with foreclosure even though Leibrock actively participated in its government-sponsored modification program and had never missed a payment. ${ }^{15}$ In the article, which features photos of Leibrock in her home, Leibrock describes how she and her husband had felt humiliated and depressed at the prospect of losing their home, but refused to "fall prey to the 'blame the victim' way of thinking." "We did nothing wrong," she wrote. "We refuse to feel ashamed." Within a week, Leibrock's article received nearly two hundred online comments, many from homeowners recounting their own struggles with lenders. After the article's publication, Leibrock heard from a government caseworker who offered to shepherd her case through Coldwell's modification process. Leibrock told me they chose to pursue a short sale instead. ${ }^{16}$ "It's like a divorce," she said. "You go through so much that you eventually look around the house and it's like you can't even remember what you loved about someone."

Like Leibrock, not all homeowners sought the protection of online anonymity. Some participated in social networks such as Facebook and Twitter, which often link online and offline identities by making profiles visible in a semipublic arena populated by one's friends, relatives, and acquaintances in ways that indicate that the multivalent ability of online domains allowed them to become crucial publics in moments of upheaval. Among my interviewees, some homeowners in their late twenties through early forties confessed to financial hardships on social networking sites and posted images of their homes on Instagram and Tumblr. For example, Sara Jiménez, a Latina thirty-five-year-old unemployed kindergarten teacher and self-described "mom blogger," described chronicling her foreclosure experiences on Facebook as an important way to "emotionally process what was happening." Her posts often provided a sarcastic spin on her foreclosure trials. One post accompanied by a photograph showing her belongings in boxes on moving day read, "I hate moving . . . Living the american dream?" The fact that social media enabled homeowners to testify to the emotional toll of financial struggles considered taboo in offline interactions suggests that users can experience catharsis just from having Facebook followers to witness their suffering (Miller 2011, 172).

Despite the public tendency to conflate anonymous and semipublic digital forums under the rubric of Web 2.0 interactive media, these two modes created fundamentally distinct outlets for homeowners who faced financial hardship and underwater mortgages after the mortgage crash. The transformative potential of 
anonymous online publics such as Reddit and Craigslist allowed homeowners to abandon mortgage debt as a moral response to widespread foreclosures. Participants operating from behind anonymizing monikers advocated bankruptcy, mortgage default, and squatting without payment as mimetic responses to the unethical and immoral practices of financial institutions. The anonymity of these domains enabled users, detached from any requirement to reveal their identities, to experience a freedom of collective participation and to question the dispossessions resulting from neoliberal financial regimes.

Unlike participants in anonymous forums, homeowners who publicly linked their online and offline identities - either through sharing their narratives and photos, like Leibrock, or by posting in online social networks - focused more on the individual, affective, and sentimental qualities of debt obligations. Leibrock, for example, focused on her shame, humiliation, and frustration; she compared the process to the dissolution of a marriage and found sharing her feelings cathartic. Her decision to pursue a short sale held a marginal role in her story, whereas the great emotional toll of the process motivated her to go public. By publicizing personal experience, semipublic online domains appropriate the technologies of speed and automation to present an affective universe that undercuts the supposedly rational and objective domain of financial decision-making. Indeed, despair becomes a central force in the formation of an alternative affective public sphere (Cvetkovich 2007).

While anger, frustration, and outrage are present in both anonymous and semipublic online communities, the distinct forms of publicity of each generate specific forms of contestation. We might liken semipublic online publics to the "communities of sentiment" that Arjun Appadurai $(1996,8)$ describes in his postelectronic expansion of imagined communities (Anderson 1983), which, he argues, have the potential to move from "shared imagination to collective action." Whereas Appadurai focuses on transnational flows of film and media as forms of electronic capitalism that create the possibility for otherwise unimaginable forms of social action, interactive web-based social networks intensify these feelings of communal belonging. The distinct forms of circulation and publicity provided by social networking sites led participants to focus on sentiment as a form of action, as participants rarely placed the same emphasis on the moral valence of canceling debts found in anonymous forums. The experience of participating within an online public that saw itself as social and connected offered novel affective orientations toward debt, but it still tethered mortgagors to expectations of debt repayment that did not directly challenge the social contract implicit in postwar 
mortgage obligations. When posting on social networks like Facebook, homeowners remained connected to each other and upheld their duty to repay debts or, if unable to repay, felt obliged to justify themselves.

One important exception to the affective dimensions and politically circumscribed nature of semipublic forums emerged on housing-activist blogs, in which participants also linked offline and online forms of identity by posting their images, but frequently advocated mortgage default as they criticized the banks and the government. For example, America Underwater, an activist blog launched jointly by nonprofits Rebuild the Dream and The New Bottom Line, encouraged homeowners with underwater loans to upload images of themselves holding signs showing how much they owed, accompanied by their personal stories. ${ }^{17}$ On this blog, a diverse group of homeowners - men and women of white, African American, and Latino descent, teens whose families were going through foreclosure, baby boomers, seniors, and retirees — offered their individual stories, some even signing their names, to create a collective narrative that linked their individual sentiments of despair to mishandling by the mortgage industry and government officials, to whom they ascribed responsibility for foreclosures. Yet in many ways,

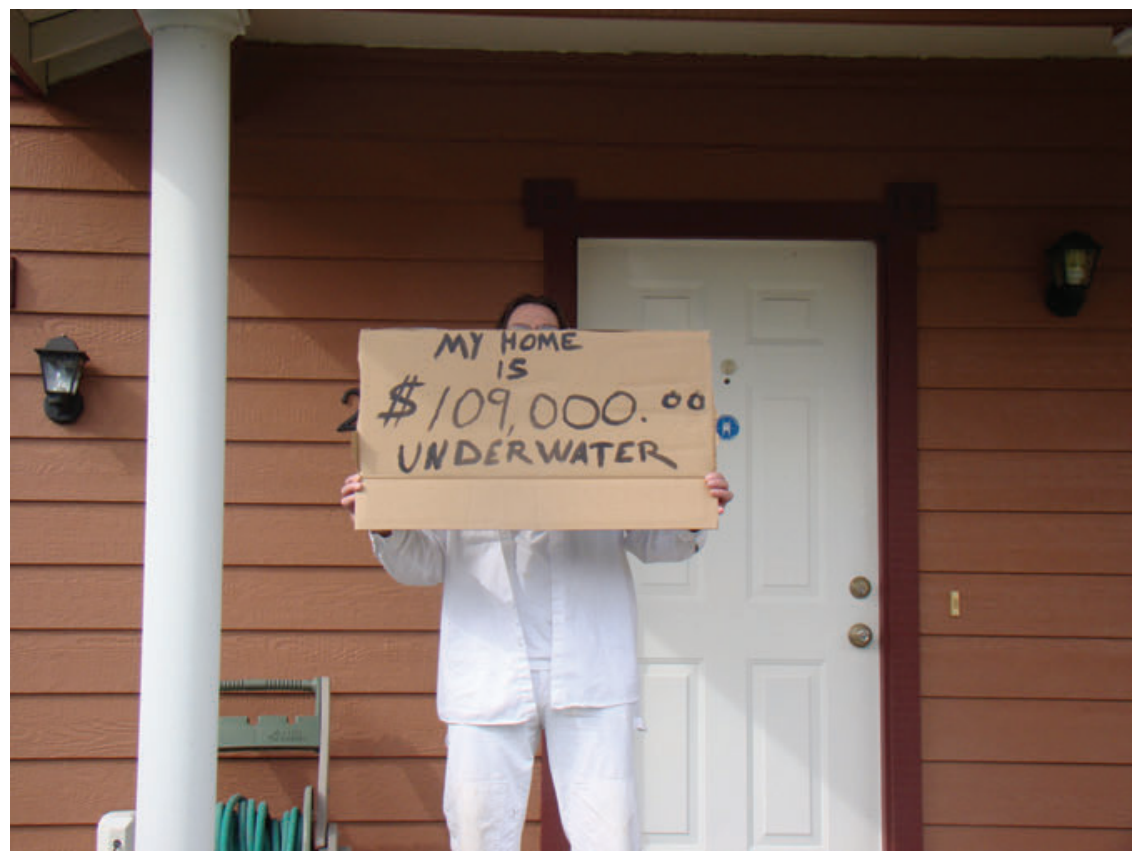

Figure 1. An anonymous homeowner holds up a sign indicating the amount by which her mortgage is underwater. Uncredited photo, http://america-underwater.tumblr.com/page/8. 
the general principle that anonymity fostered more radical stances on debt refusal held true in these activist blogs. In their photographic posts on America Underwater, for example, many homeowners used their signs to obscure their faces and left their narratives unidentifiable, indicating a desire to maintain anonymity.

Even those who participated in online activist publics found anonymity, rather than semipublicity, a more acceptable stance from which they could advocate for the abandonment of mortgage debts.

\section{DISCIPLINING THE POLITICS OF DEFAULT}

Anonymous online users encouraged each other to default, declare bankruptcy, and squat in their homes while the banks dealt with backlogs of foreclosures. But not all posters on anonymous forums bought wholeheartedly into reformulated views arising from economic hardship. Instead, many posters resisted the indiscriminate democratization of acts of debt refusal. Even as anonymous online exchanges generated counternarratives of mortgage default, in many discussion threads posters suggested new forms of discipline to determine which homeowners qualified for respectable forms of default. By reframing only some forms of mortgage default as moral and ethically sound, users marked others as ethically suspect.

Anonymous online forums often erupted in impassioned debates and outright attacks on posters who advocated strategic mortgage default, which occurs when a homeowner can afford to pay his or her mortgage but nonetheless walks away. In one case, a Reddit user called Tvisforbabyboomers set off a firestorm when he described not feeling humiliated as he initiated strategic mortgage default:

My wife and I are foreclosing on purpose. We live a middle class lifestyle and can afford our house, but our mortgage is "no longer sustainable." . . . Our house is $\$ 150,000$ underwater. . . . We do not feel guilty about not paying our mortgage to our bank because when we asked for refinance assistance months ago, they said "google it" (seriously, they did). Furthermore, our mortgage is probably insured, so they will end up getting money anyway. Besides, it is business . . . the banks got bailed out, wall street got bailed out . . . and I'm middle class, this is my bail out. . . . De-Occupy your home. ${ }^{18}$

While most users, like McGill and Suarez, justified nonpayment by criticizing lenders' dishonesty, they stopped short of promoting wide-scale debt refusal. In contrast, Tvisforbabyboomers politicized his decision by drawing on an Occupy 
Wall Street discourse that blamed the government and banks for the crisis while, paradoxically, drawing on a financial discourse to assert that mortgage default is a business decision, not an ethical one. Other commentators, however, attacked Tvisforbabyboomers and others like him, accusing them of adopting an "entitlement mentality." They derided borrowers' unwillingness to pay despite lack of hardship, such as unemployment or health crises, suggesting that these unscrupulous homeowners were unlike themselves, who were "hit hard by the crisis" and only forced into mortgage default by uncooperative lenders.

Unlike mainstream media representations, which did not suggest mortgage default as a viable option, these online discourses distinguished between a universe of morally appropriate mortgage default - in which bad things happened to good people despite their best efforts to uphold their end of the bargain - and one of selfish greed and irresponsible borrowing. Arguments strikingly similar to those in the Reddit thread, which sought to parse deserving victims from irresponsible overspenders, were deployed across online housing forums. In another Reddit thread, a homeowner who had bought a condo for $\$ 135,000$ and owed $\$ 155,000$ at the time of posting solicited advice on how to walk away. UnamusedPunk responded, "Your biggest problem is blaming everyone else for your problems, it is no one elses fault but your own that you didnt have a job for two years. IT IS ALL YOUR FAULT, ALL OF IT."19

Although online forums ostensibly presented a color- and class-blind public sphere, given the anonymity of participants, the discourses produced online frequently included biting expressions of racial and class discrimination. A recurring claim in various threads was that homeowners had bought homes they could not afford, blindly agreed to subprime loans, or were already chronically unemployed before the Great Recession. The racialized and class-based implications of the comments become clearer when we consider that African American and Latino homeowners were twice as likely as whites to be targeted by subprime lenders, even when they qualified for traditional, fixed-rate mortgages (Bocian et al. 2011). Likewise, working-class African American, Latino, and white homeowners often needed to borrow more to cover a mortgage on a basic, modest home, given the real decrease in income and rising costs of living since the $1980 \mathrm{~s} .{ }^{20}$ On forums, as in the mainstream media, working-class homebuyers were accused of leveraging mortgages to purchase McMansions, boats, RVs, and luxury vacations. In reality, they typically used these loans to purchase modest homes, pay for their children's educations, and meet daily living expenses. Yet when identifiably non-middleclass homeowners proposed defaulting on their loans, they were rarely supported, 
suggesting the re-emergence of the pre-World War II stigma against workingclass people who borrow and owe money. Nonpayment was given a positive moral valence for middle-class homeowners, but debt and default were still shameful for those with the greatest need. ${ }^{21}$

The anonymity of these forums enabled commenters to express great fervor and disdain. One popular Reddit user, for example, read through the archives of a New Jersey poster named Djspacebunny to attack her pleas for advice on an impending foreclosure. Citing her earlier posts with links, he accused her of being a lazy opiate addict who was trying to scam the system through malpractice lawsuits and bankruptcy, rather than a deserving, hardworking homeowner trying to do the right thing. He implored his fellow Reddit users to refuse to give her advice. $^{22}$ When other Reddit users criticized his rampage against Djspacebunny, he eventually removed his posts, but his impulse to police which posters were respectable enough to deserve guidance speaks to a recurring theme throughout the threads. If online privacy allows homeowners to participate in public dialogue, it also emboldens attacks on users who challenge longstanding notions of middleclass propriety. Through anonymous comments, online participants recalibrated the moral meanings of abandoning debts — but only to a point. ${ }^{23}$

\section{THE MORAL VALENCE OF DEBT ABANDONMENT}

Since the start of the Great Recession, analysts have revisited enduring questions about the moral valence of debt, the calculation of financial risk, and the necessity of regulating against unbridled greed within American capitalism. Yet many have suggested that these discussions have not gone far enough. They point out that Wall Street firms, bolstered by billion-dollar bailouts, have returned to business as usual, while any significant signs of social change have dissipated as Occupy protesters have packed up their tents. In his recent opus on debt, David Graeber $(2011,17)$, for example, suggests that these public debates initially promised to reveal the moral basis of market exchange, but then "sputtered into incoherence." The online forays of California homeowners caught in the grips of the 2008 crash and its protracted aftermath suggest otherwise: the longstanding social contract implicit within mortgage debt ties is losing its hold.

In the Sacramento Valley, homeowners who participated in online publics were influenced by others' decisions to reconfigure the morality of default in ways that challenge established interpretations of mortgage debt as the responsibility of the borrower alone. These significant shifts occur even as mainstream media narratives deride homeowners defaulting on mortgages and frame the absence of 
foreclosure stigma as a "contagion" that spreads the likelihood of default through neighborhoods (Chan et al. 2013, 101). Homeowners turning to online collectivities likewise changed their thinking about mortgage debt as they received advice from others in similar situations. They realized how many Americans struggled with unemployment, a rapid decline in home equity, and rising health-care costs, and they found the accessibility and privacy of online forums a particularly appealing means to navigate this foreboding landscape. Based on this evidence, I argue that anonymous participation in online domains such as Reddit and Craigslist housing forums presents opportunities to attach a positive moral valence to the abandonment of debt obligations for specific homeowners, whereas semipublic participation on social networking sites and public writing on blogs create new avenues for questioning the shame and humiliation that have accompanied postwar moral judgments about default.

The forms and mediums of both semipublic and anonymous online publics of indebtedness, not just their content, generated experiential qualities that inspired participants to reconsider, in different ways, the meaning of underwater mortgage debts. For my respondents, anonymous participation in online publics produced an experience of untethered freedom while still linking participants' experiences to broader collectivities. For example, participants in anonymous Reddit and Craigslist housing forums could challenge the authority of broadcast news narratives, formulating alternative moral economies that included abandoning insurmountable debts. Participation on semipublic domains such as Facebook and blogs encouraged participants to rethink the affective meaning of mortgage debts, moving from shame and stigma to outrage. These trends suggest a complex and unexpected convergence between digital media and neoliberalism, as interactive web platforms reinforce the autological premises of late liberalism while, simultaneously, leading those dispossessed by neoliberal financial regimes to question those institutions' role in perpetuating omnipresent debt economies. ${ }^{24}$

How do we classify the influence of homeowners experiencing foreclosure in lower-middle- and middle-class neighborhoods who, online, advocate new moral and affective stances in relation to debt but do not recognize these orientations as political? ${ }^{25}$ Anthropologists have shown how digital technologies have been used for traditional political aims, such as mobilizing support for the indigenous Zapatista movement in Mexico (Castells 2001) and coordinating protests across national borders (Juris 2008; Shirky 2008), as was the case during the Arab Spring, but the transformations in perspective I am studying operate more clandestinely, making them more difficult to detect and analyze. Within anonymous 
and semipublic online domains, homeowners generated new affective orientations toward indebtedness and revised cultural conceptions of the morality of abandoning overwhelming debts; some then carried these conceptions into other social spheres by walking away from their mortgages. While resistant to collective political mobilization in a traditional sense, mortgagors with opposing political affiliations and worldviews often joined in online dialogue in a populist-inflected counterpoint to dominant narratives of immoral defaulters that is significant in its own right.

Across both anonymous and semipublic domains, online publics represent a significant expansion of American middle-class milieus and narrative resources to include diverse forms of digital sociality. Specifically, online publics shaped the expression and interpretation of indebtedness as a distinct part of an American lower-middle- and middle-class habitus, at a moment when these social positions were increasingly precarious. Participants within anonymous online publics drew on cultural capital to sort through uncensored and nonexpert online advice and to incorporate that guidance into their preexisting knowledge about debt, finance, and the moral valence of repayment. Those posting in semipublic online social networks described a sense of security that allowed them to share their hardships with their friends and family members online. These forms of online connectivity not only revised middle-class ideas about the moral underpinnings of indebtedness but also reflected and reproduced forms of social inequality by extending socioeconomic disparities into a new, virtual terrain.

Just as the technological apparatus of subprime lending, such as risk algorithms and automated debt-to-income ratios, disproportionately affected African American and Latino homeowners in low-income neighborhoods, participants managing indebtedness through these online technologies also excluded the most marginalized homeowners. Indeed, more in-depth research is needed to analyze how the intersections of class, ethnicity, and race influence the appeal and efficacy of online publics. As Margaret Atwood (2008, 41) points out in Payback, debt, like smoking cigarettes and drinking alcohol, has gone out of fashion-what was once considered harmless is now considered a sin to be avoided at all costs. Those Americans who are forced to rely on debt to finance the necessities of daily life, therefore, are once again seen as suffering a lapse in discipline and moral personhood that needs to be rectified.

My examination here of the "prosaics of the digital," or how digital media reflect and shape social practices (Coleman 2010), indicates a significant reorganization of debt imaginaries that reflects and extends a nationwide kitchen-table 
discussion about the culpability of mortgage lenders and the morality of abandoning unfair debt burdens. Although these online publics might seem fleeting, coalescing around crises and eventually succumbing to broken links and obsolete Internet browsers, the ways in which they participate in a larger restructuring of debt refusal promise to endure. While online forums emboldened middle-class homeowners to resist moral responsibility for distressed mortgage debt, these homeowners also sought to rediscipline the significance and virtue of mortgage default by determining who may respectably abandon underwater loans. Ultimately, the rise of such publics suggests how narratives that question the repayment of debt as central to moral personhood might gain traction through emerging technological forms of sociality and self-expression, virtual encounters that highlight the disorder of contemporary capitalism and play a significant role in redefining how Americans understand the debts they owe one another.

\section{ABSTRACT}

The 2008 mortgage crash and the online publics that have emerged in its aftermath have reshaped American interpretations of indebtedness. Combining research among homeowners facing foreclosure in California's Sacramento Valley with an analysis of the national online forums they frequent, I show how participants rethink the moral scaffolding of debt relations within what I describe as online publics of indebtedness. Anonymous online publics foster experiences of disembodied autonomy that encourage debt refusal and discipline the middle-class ethics of debt abandonment, as participants distinguish between mortgagors who deserve not to pay their debts and those they deem irresponsible for defaulting on their loans. In contrast, participation in semipublic social networks and online forms of publicity emphasizes new affective orientations toward debt obligations. My analysis contributes to an anthropological scholarship on moral economies by exploring the role of distinct forms of new media in shaping everyday experiences of indebtedness in late-capitalist financial markets. [online; publics; debt; moral economies; mortgage default; United States]

\section{NOTES}

1. An underwater mortgage is one in which the amount owed exceeds the property's current value.

2. For an overview of the valuation of credit and the morally suspect nature of debt within anthropological discussions, see Peebles 2010 and Gregory 2012.

3. As Tom Boellstorff (2012) emphasizes, ethnographies of online communities require deeper involvement than isolated interviews and textual readings.

4. As scholars have recently shown, online domains hold the same social potential and problems as any arena of offline life (Boellstorff 2008; Ginsburg 2008; Miller and Horst 2012).

5. Mortgaging and foreclosure reflect culturally specific and historically shifting ideas about homeownership, debt, and seizure (Graeber 2011; Maurer 2006; Shipton 2009).

6. Although the repossession of goods has long been reserved for the working poor rather 
than middle-class households that fail to pay debts (Hyman 2011b, 204), foreclosure is a key exception to this trend.

7. This belief is found among those living in middle-class neighborhoods across the nation (Heiman, Freeman, and Liechty 2012, 8).

8. Unlike the government buyout of homeowners' bad loans during the mortgage crash that preceded the Great Depression, legislators passed policies that privatized assistance programs, leaving lenders to adjudicate homeowners' appeals and to refuse to modify distressed mortgages.

9. While there are literally thousands of examples of these media discussions, a few illustrations include Lowenstein 2010, Armour 2009, and Harney 2009.

10. Brent White (2010b) references specific shows such as Fox's Your World with Cavuto, "The Deal: Walk Away from Your Home"; The Mike Gallagher Show, "YouWalkAway.com"; and 60 Minutes, "The U.S. Mortgage Meltdown."

11. As Janet Roitman (2013) attests, a range of pundits trace a chain of events by which the "housing market fell" and homeowners lost equity and defaulted on their mortgages. The critical question of why housing prices began to fall, Roitman $(2013,57)$ suggests, is preemptively excluded.

12. For professionals working in office jobs, these online sessions proved appealing because they could take place surreptitiously during work hours. For homeowners with jobs in the service industries, online searches and participation were unrestricted to business hours and could commence after long workdays.

13. Craigslist discussion forums also harbor a robust community, with more than 200 million users and one hundred topical forums. As of 2012, Reddit, a site with over 1 million registered users, was divided into more than 100,000 "subreddits," or topic threads, and garnered 34.9 million unique views each month.

14. Due to the public nature of Leibrock's article, I have used her real name with her permission. All other names of homeowners are pseudonyms.

15. A representative from Coldwell told Leibrock that she should have been making her regular payments in addition to the trial modification payments to prevent default.

16. In a short sale, the proceeds from the sale will not cover the amount owed on the mortgage. Sometimes, though not always, the lender might prefer to absorb a moderate loss on the sale than have a homeowner default on a loan. The homeowner's credit is still damaged.

17. A progressive organization founded by the Obama advisor Van Jones, Rebuild the Dream, draws on digital technologies to campaign for social issues. See http://www. rebuildthedream.com/support_for_homeowners.

18. The thread can be viewed at http://www.reddit.com/r/Frugal/comments/sm $8 \mathrm{kr} /$ i_got_hit_hard_by_the_crash_and_im_going_through_a_foreclosure.

19. The thread can be viewed at http://www.reddit.com/r/AskReddit/comments/ 11dzxs/my_condo_i_bought_when_i_was_22_has_been_in.

20. By the 1980 s, many Americans faced a landscape less similar to the postwar era than to the 1920s, when consumer credit was used to shore up shortcomings from shortterm unemployment and decreased income (Hyman 2011a, 99).

21. This dynamic is apparent in the rise of what Brett Williams (2004) describes as "debt porn," reality television shows in which Americans are shamed for their debts, repent, and promise to change their ways.

22. The thread can be viewed at http://www.reddit.com/r/newjersey/comments/10ycis/ nj_help_a_sister_out_im_going_to_lose_my_house.

23. The anonymity of the sites is not absolute, as users might post otherwise private financial information in ways that raise pressing questions about the use of these data. Joe Deville (2013), for example, shows how an online loan company uses "leaky data," such as the browser and the device with which users access the site, as well as their Facebook activity, to determine the risk of a borrower and the interest rate a borrower is charged.

24. My findings offer a starting point for understanding what Dominic Boyer (2013, 135) sees as the phenomenological juncture between digital media and neoliberalism, through 
which mobile media make late liberal discourse seem intuitive, while the interfaces promise to give the experience of autological freedom.

25. My findings advance Hannah Appel's (2014) claim that experiences of the 2008 crash and its aftermath have inspired a reimagining of capitalism. Analyzing the stories of individuals working in Wall Street banks who eventually joined Occupy Wall Street, Appel shows how her collaborators were radicalized after witnessing the unethical maneuvers of their colleagues and institutions leading up to the crash.

\section{REFERENCES}

Appadurai, Arjun

1996 Modernity at Large: Cultural Dimensions of Globalization. Minneapolis: University of Minnesota Press.

Appel, Hannah

2014 “Occupy Wall Street and the Economic Imagination.” Cultural Anthropology 29, no. 4: 602-25. http://dx.doi.org/10.14506/ca29.4.02.

Anderson, Benedict

1983 Imagined Communities: Reflections on the Origins and Spread of Nationalism. London: Verso.

Armour, Stephanie

2009 “More Walk Away from Homes, Mortgages.” USA Today, November 3. http:// usatoday30.usatoday.com/money/economy/housing/2009-11-02-voluntary-

Atwood, Margaret foreclosure_N.htm.

2008 Payback: Debt and the Shadow Side of Wealth. Toronto: House of Anansi Press.

Baker, Christi, Kevin Stein, and Mike Eiseman

2008 "Foreclosure Trends in Sacramento and Recommended Policy Options." Report for the Sacramento Housing and Redevelopment Agency by the California Reinvestment Coalition. http://www.shra.org/LinkClick.aspx?fileticket= WaDLuiUtot5s\%3D\&tabid $=103 \& \mathrm{mid}=454$.

Berlant, Lauren, ed.

2000 Intimacy. Chicago: University of Chicago Press.

Bocian, Debbie Gruenstein, Carolina Reid, Roberto G. Quercia, and Wei Li

2011 "Lost Ground, 2011: Disparities in Mortgage Lending and Foreclosures.” Durham, N.C.: Center for Responsible Lending. http://www.responsiblelending.org/ research-publication/lost-ground-2011.

Boellstorff, Tom

2008 Coming of Age in Second Life. Princeton, N.J.: Princeton University Press.

2012 Ethnography and Virtual Worlds: A Handbook of Method. Princeton, N.J.: Princeton University Press.

Boyer, Dominic

2007 Understanding Media: A Popular Philosophy. Chicago: Prickly Paradigm Press.

2013 The Life Informatic: Newsmaking in the Digital Era. Ithaca, N.Y.: Cornell University Press.

Calder, Lendol

1999 Financing the American Dream: A Cultural History of Consumer Credit. Princeton, N.J.: Princeton University Press.

Castells, Manuel

2001 The Internet Galaxy: Reflections on the Internet, Business, and Society. Oxford: Oxford University Press.

Chakravartty, Paula, and Denise Ferreira da Silva

2012 "Accumulation, Dispossession, and Debt: The Racial Logic of Global Capitalism-An Introduction.” American Quarterly 64, no. 3: 361-85. http:// dx.doi.org/10.1353/aq.2012.0033. 
Chan, Sewin, Michael Gedal, Vicki Been, and Andrew Haughwout

2013 "The Role of Neighborhood Characteristics in Mortgage Default Risk: Evidence from New York City.” Journal of Housing Economics 22, no. 2: 100-18. http://

Coleman, E. Gabriella dx.doi.org/10.1016/j.jhe.2013.03.003.

2010 "Ethnographic Approaches to Digital Media." Annual Review of Anthropology 39: 487-505. http://dx.doi.org/10.1146/annurev.anthro.012809.104945.

Cvetkovich, Ann

2007 “Public Feelings.” South Atlantic Quarterly 106, no. 3: 459-68. http://dx.doi. org/10.1215/00382876-2007-004.

Deville, Joe

2013 "Wonga is Watching You . . . How Payday Lenders Follow Your Online Trail." The Conversation, May 21. http:// theconversation.com/wonga-is-watching-youhow-payday-lenders-follow-your-online-trail-14541.

Dudley, Kathryn Marie

2000 Debt and Dispossession: Farm Loss in America's Heartland. Chicago: University of Chicago Press.

Edelman, Marc

2005 "Bringing the Moral Economy back in . . . to the Study of Twenty-First-Century Transnational Social Movements." American Anthropologist 107, no. 3: 331-45. http://dx.doi.org/10.1525/aa.2005.107.3.331.

Fannie Mae

2010 "New Nationwide Survey Provides Comprehensive Look at Sentiment toward Housing." Press release, April 6. http://www.fanniemae.com/portal/aboutus/media/corporate-news/2010/4989.html.

Fraser, Nancy

1990 "Rethinking the Public Sphere: A Contribution to the Critique of Actually Existing Democracy." Social Text, nos. 25-26: 56-80. http://dx.doi.org/ $10.2307 / 466240$.

Ginsburg, Faye

2008 "Rethinking the Digital Age." In The Media and Social Theory, edited by David Hesmondhalgh and Jason Toynbee, 127-44. New York: Routledge.

2012 “Disability in the Digital Age." In Digital Anthropology, edited by Heather A. Horst and Daniel Miller, 101-26. London: Berg.

Goodman, Peter S.

2012 "Eminent Domain as Underwater Mortgages Fix: Why Some Cities are Considering Unorthodox Measure." Huffington Post, October 1. http://www. huffingtonpost.com/2012/10/01/eminent-domain-

Graeber, David mortgages_n_1917391.html.

2011 Debt: The First 5,000 Years. New York: Melville House.

Gregory, Chris A.

2012 "On Money Debt and Morality: Some Reflections on the Contribution of Economic Anthropology.” Social Anthropology 20, no. 4: 380-96. http://dx.

Griffith, David doi.org/10.1111/j.1469-8676.2012.00225.x.

2009 “The Moral Economy of Tobacco.” American Anthropologist 111, no. 4: 432-42. http://dx.doi.org/10.1111/j.1548-1433.2009.01153.x.

Habermas, Jürgen

1989 Structural Transformation of the Public Sphere: An Inquiry into a Category of Bourgeois Society. Translated by Thomas Burger, with the assistance of Frederick Lawrence. Cambridge, Mass.: MIT Press. Originally published in 1962. 
Harney, Kenneth R.

2009 “Good Credit Scores, Deadbeat Choices." Washington Post, November 19. http://www.washingtonpost.com/wp-dyn/content/article/2009/09/18/ AR2009091800071.html.

Heiman, Rachel, Carla Freeman, and Mark Liechty

2012 "Introduction: Charting an Anthropology of the Middle Classes." In The Global Middle Classes: Theorizing Through Ethnography, 3-29. Santa Fe, N.M.: School for Advanced Research.

High, Holly

2012 "Re-Reading the Potlatch in a Time of Crisis: Debt and the Distinctions that Matter." Social Anthropology 20, no. 4: 363-79. http://dx.doi.org/10.1111/ j.1469-8676.2012.00218.x.

Ho, Karen Z.

2009 Liquidated: An Ethnography of Wall Street. Durham, N.C.: Duke University Press.

2010 "Outsmarting Risk: From Bonuses to Bailouts." Anthropology Now, May 14. http: / / anthronow.com/online-articles/outsmarting-risk-from-bonuses-tobailouts.

Hyman, Louis

2011a Debtor Nation: The History of America in Red Ink. Princeton, N.J.: Princeton University Press.

2011b "Ending Discrimination, Legitimating Debt: The Political Economy of Race, Gender, and Credit Access in the 1960s and 1970s." Enterprise and Society 12, no. 1: 200-32. http://dx.doi.org/10.1017/S1467222700009770.

Jefferson, Anna

2013 "Narratives of Moral Order in Michigan's Foreclosure Crisis." City and Society 25, no. 1: 92-112. http://dx.doi.org/10.1111/ ciso.12006.

Juris, Jeffrey $\mathrm{S}$.

2008 Networking Futures: The Movements against Corporate Globalization. Durham, N.C.: Duke University Press.

Langley, Paul

2007 “The Uncertain Subjects of Anglo-American Financialization." Cultural Critique, no. 65: 66-91. http://dx.doi.org/10.1353/cul.2007.0009.

Lowenstein, Roger

2010 “Walk Away from Your Mortgage!” New York Times Magazine, January 7. http:// www.nytimes.com/2010/01/10/magazine/10FOB-wwln-t.html.

Maurer, Bill

2006 Pious Property: Islamic Mortgages in the United States. New York: Russell Sage.

Miller, Daniel

2011 Tales from Facebook. Cambridge: Polity.

Miller, Daniel, and Heather A. Horst

2012 “The Digital and the Human: A Prospectus for Digital Anthropology." In Digital Anthropology, edited by Heather A. Horst and Daniel Miller, 3-35. London: Berg.

Negt, Oskar, and Alexander Kluge

1993 Public Sphere and Experience: Toward an Analysis of the Bourgeois and Proletarian Public Sphere. Translated by Peter Labanyi, Jamie Owen Daniel, and Assenka Oksiloff. Minneapolis: University of Minnesota Press. Originally published in 1972.

Newman, Katherine S.

1988 Falling from Grace: Downward Mobility in the Age of Affluence. Berkeley: University of California Press.

Peebles, Gustav

2010 "The Anthropology of Credit and Debt." Annual Review of Anthropology 39: 22540. http://dx.doi.org/10.1146/annurev-anthro-090109-133856. 
Pinch, Trevor, and Richard Swedberg, eds.

2008 Living in a Material World: Economic Sociology Meets Science and Technology Studies. Cambridge, Mass.: MIT Press.

Poon, Martha

2008 "From New Deal Institutions to Capital Markets: Commercial Consumer Risk Scores and the Making of Subprime Mortgage Finance." Accounting, Organizations,

Postill, John and Society 34, no. 5: 654-74. http://dx.doi.org/10.1016/j.aos.2009.02.003.

2012 “Digital Politics and Political Engagement." In Digital Anthropology, edited by Heather A. Horst and Daniel Miller, 165-84. London: Berg.

Reid, Carolina

2010 "Sought or Sold? Social Embeddedness and Consumer Decisions in the Mortgage Market." Federal Reserve Bank of San Francisco Working Paper. http:// www.frbsf.org/community-development/publications/working-papers/2010/ Roitman, Janet december/mortgage-market-social-networks-consumer-decision/.

2005 Fiscal Disobedience: An Anthropology of Economic Regulation in Central Africa. Princeton, N.J.: Princeton University Press

2013 Anti-Crisis. Durham, N.C.: Duke University Press.

Ross, Andrew

2013 Creditocracy and the Case for Debt Refusal. New York: OR Books.

Scott, James C.

1977 The Moral Economy of the Peasant: Rebellion and Subsistence in Southeast Asia. New Haven, Conn.: Yale University Press.

Shimpach, Shawn

2012 "Realty Reality: HGTV and the Subprime Crisis." American Quarterly 64, no. 3: 515-42. http://dx.doi.org/10.1353/aq.2012.0032.

Shipton, Parker

2009 Mortgaging the Ancestors: Ideologies of Attachment in Africa. New Haven, Conn.: Yale University Press.

Shirky, Clay

2008 Here Comes Everybody: The Power of Organizing Without Organizations. New York: Penguin.

Squires, Catherine R.

2012 "Coloring in the Bubble: Perspectives on Black-Oriented Media on the (Latest) Economic Disaster.” American Quarterly 64, no. 3: 543-70. http://dx.doi.org/

Thompson, E.P. 10.1353/aq.2012.0034.

1971 "The Moral Economy of the English Crowd in the Eighteenth Century." Past \& Warner, Michael

Present, no. 50: 76-136. http://www.jstor.org/stable/650244.

2002 Publics and Counterpublics. New York: Zone.

White, Brent T.

2010a "The Morality of Strategic Default." UCLA Law Review Discourse 58, 155-64. http://www.uclalawreview.org/the-morality-of-strategic-default/.

2010b "Underwater and Not Walking Away: Shame, Fear and the Social Management Williams, Brett of the Housing Crisis." Wake Forest Law Review 45: 971.

2004 Debt for Sale: A Social History of the Credit Trap. Philadelphia: University of Pennsylvania Press. 